\title{
Pembelajaran hubungan antar sudut menggunakan model pembelajaran guided inquiry
}

\author{
Sundari Gita Pertiwi ${ }^{1}$ (iD), Rully Charitas Indra Prahmana ${ }^{1 *}$ \\ ${ }^{1}$ Department of Mathematics Education, Universitas Ahmad Dahlan, Yogyakarta, Indonesia \\ * Corresponding Author. E-mail: rully.indra@mpmat.uad.ac.id
}

\begin{tabular}{|c|c|}
\hline ARTICLE INFO & ABSTRACT \\
\hline $\begin{array}{l}\text { Article History: } \\
\text { Received: } 31 \text { Oct. } 2020 \\
\text { Revised: } 17 \text { Dec. } 2020 \\
\text { Accepted: } 28 \text { Dec. } 2020 \\
\text { Keywords: } \\
\text { Pembelajaran hubungan } \\
\text { antar sudut, } \\
\text { Pemahaman matematis, } \\
\text { Guided inquiry learning } \\
\text { model, } \\
\text { Inter-angular relationships } \\
\text { learning, } \\
\text { Mathematical understan- } \\
\text { ding. }\end{array}$ & $\begin{array}{l}\text { Materi geometri merupakan materi yang penting untuk dipelajari karena berkaitan dengan } \\
\text { kehidupan sehari-hari dan sebagai materi dasar pendukung penguasaan materi matematika } \\
\text { yang lain. Namun, materi geometri, khususnya materi hubungan antar sudut, masih dianggap } \\
\text { sulit dipahami oleh siswa. Oleh karena itu, dibutuhkan suatu model pembelajaran yang interaktif } \\
\text { dan dapat menuntun siswa menemukan sendiri konsep yang dipelajari untuk mengembangkan } \\
\text { pemahaman mereka. Salah satu model pembelajaran alternatif yang dapat digunakan adalah } \\
\text { model guided inquiry atau penyelidikan terbimbing yang mana dalam model pembelajaran ter- } \\
\text { sebut siswa adalah pusat pembelajaran dan guru adalah fasilitator dan motivator belajar siswa. } \\
\text { Penelitian ini menggunakan metode deskriptif kualitatif untuk mendeskripsikan proses pembe- } \\
\text { lajaran yang menerapkan model guided inquiry. Penelitian dilaksanakan di SMP Negeri } 3 \text { Bantul, } \\
\text { Daerah Istimewa Yogyakarta dengan subyek penelitian yaitu siswa kelas VII ( } n=32 \text { ). Data pene- } \\
\text { litian dikumpulkan dalam bentuk rekaman audio dan video, foto, dan lembar aktivitas siswa. } \\
\text { Data dianalisis dengan cara mereduksi, menampilkan, dan menyimpulkan data, setelah itu di- } \\
\text { tulis dalam bentuk narasi deskriptif. Hasil penelitian menunjukkan bahwa implementasi model } \\
\text { guided inquiry dalam pembelajaran hubungan antar sudut yang terdiri atas tiga pertemuan } \\
\text { dengan beberapa aktivitas pembelajaran mendeskripsikan proses pembelajaran yang baik. }\end{array}$ \\
\hline 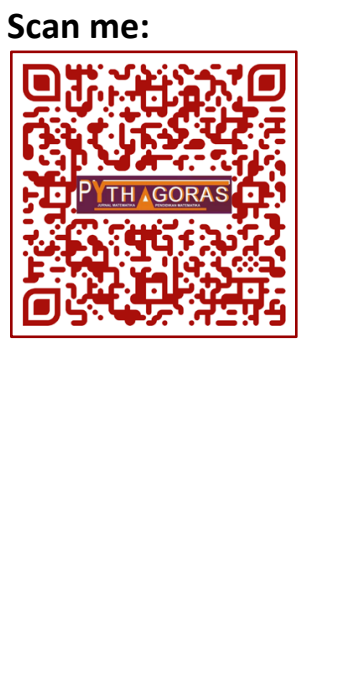 & $\begin{array}{l}\text { Geometry is one of the essential materials to learn because it is related to everyday life and as } \\
\text { basic material to support mastery ofothermathematics materials. However, the material of geo- } \\
\text { metry, especially the material on the inter-angular relationships, is still considered hard to be } \\
\text { understood by students. Therefore, there is a need for a learning model that is more interactive } \\
\text { and can provide guidance for students to find the concepts by themselves. One of the alternative } \\
\text { learning models that can be used is the guided inquiry, wherein that learning model, the students } \\
\text { are the center of learning and the teacher is the facilitator and motivator of students' learning. } \\
\text { This research employed a descriptive qualitative method to describe the learning process that } \\
\text { implemented the guided inquiry model. The research was conducted at one of the public junior } \\
\text { high schools in the Special Region of Yogyakarta, namely SMP Negeri } 3 \text { Bantul in which the } \\
\text { subject was } 32 \text { seventh graders. The research data were collected in the form of audio and video } \\
\text { recordings, photos, and student activity sheets. The data were analyzed by reducing, presenting, } \\
\text { and concluding, then it was written in the form of descriptive narration. The results demonstrated } \\
\text { that the implementation of the guided inquiry model in the inter-angular relationships learning } \\
\text { that consisted of three meetings with several learning activities described an excellent learning } \\
\text { process. }\end{array}$ \\
\hline
\end{tabular}

This is an open access article under the CC-BY-SA license

\section{How to Cite:}

Pertiwi, S. G., \& Prahmana, R. C. I. (2020). Pembelajaran hubungan antar sudut menggunakan model pembelajaran guided inquiry. Pythagoras: Jurnal Pendidikan Matematika, 15(2), 137-150. https://doi.org/10.21831/pg.v15i2.35415

doi) https://doi.org/10.21831/pg.v15i2.35415

\section{PENDAHULUAN}

Salah satu materi pelajaran matematika yang masih dianggap sulit dipahami oleh siswa adalah materi geometri, khususnya materi mengenai hubungan antar sudut (Fabiyi, 2017; Owens \& Outhred, 2006). Hal ini dibuktikan dengan banyak ditemukannya kesalahan siswa dalam mengerjakan soal yang berkaitan dengan konsep hubungan 
antar sudut (lihat Biber et al., 2013; Özerem, 2012). Beberapa kesalahan siswa tersebut antara lain yaitu siswa salah dalam membuat kalimat matematika, salah dalam memahami soal, salah dalam mengilustrasikan gambar hubungan antar sudut, dan kesalahan perhitungan (Ananda et al., 2018; Biber et al., 2013; Özerem, 2012; Rosdianah et al., 2019). Di sisi lain, terdapat beberapa faktor yang mungkin mempengaruhi kesulitan siswa dalam belajar atau mengerjakan soal matematika, selain faktor internal siswa seperti kemampuan, ketelitian (Hadi et al., 2018), motivasi (Retnawati et al., 2019) dan lain-lain, faktor eksternal seperti model pembelajaran konvensional yang digunakan guru juga diduga menjadi faktor utama yang mempengaruhi kesulitan tersebut (Ananda et al., 2018; Rosdianah et al., 2019).

Berdasarkan hasil observasi yang dilakukan oleh peneliti terhadap proses pembelajaran matematika untuk materi geometri, lebih spesifik pada topik hubungan antar sudut di salah satu SMP negeri di Daerah Istimewa Yogyakarta, ditemukan banyak siswa yang mengalami kesulitan dalam memahami materi hubungan antar sudut. Hal ini juga terlihat dari hasil pengerjaan soal pada Ujian Nasional (UN) tahun 2019, yang berkaitan dengan materi geometri dan pengukuran juga masih rendah, yaitu hanya 42,27\% siswa yang mampu menjawab dengan benar (Puspendik, 2019). Meskipun dalam dokumen Kurikulum 2013 telah mengamanatkan bahwa proses pembelajaran seharusnya dilaksanakan dengan pendekatan saintifik, model pembelajaran yang digunakan oleh guru di sekolah tersebut masih menggunakan model konvensional, di mana guru menjelaskan materi pembelajaran sementara siswa mendengarkan dan mencatat penjelasan dari guru tersebut. Model pembelajaran konvensional yang seperti itu tidak selalu buruk, namun model pembelajaran tersebut sering kali membuat siswa merasa bosan, dan kurang termotivasi dalam belajar, serta menjadikan pembelajaran menjadi kurang bermakna sehingga mempengaruhi pemahaman siswa terhadap yang sedang dipelajarinya (Sahrir \& Ratumanan, 2018).

Mengingat pentingnya materi geometri, termasuk hubungan antar sudut, untuk dipahami oleh siswa, maka perlu diimplementasikan suatu pendekatan atau model pembelajaran matematika yang berpotensi untuk dapat memfasilitasi proses pembelajaran dan pengembangan pemahaman siswa terhadap materi tersebut. Hal ini dikarenakan materi geometri berkaitan erat dengan kehidupan sehari-hari dan menjadi materi dasar yang mendukung penguasaan materi lain, seperti aljabar, bilangan, aritmetika, dan lain-lain (Clements \& Sarama, 2011; National Mathematics Advisory Panel, 2008; Novita et al., 2018; Panaoura, 2014; Rofii et al., 2018).

Model pembelajaran guided inquiry atau penyelidikan terbimbing diyakini dapat menjadi salah satu alternatif model pembelajaran yang dapat digunakan untuk memfasilitasi siswa dalam memahami konsep matematika, termasuk konsep hubungan antar sudut (Gunur et al., 2019). Model ini melibatkan siswa secara langsung untuk menyelidiki konsep dan menarik simpulan dari konsep yang telah diselidiki tersebut, serta guru bertindak sebagai fasilitator, sehingga yang menjadi pusat dalam pembelajaran adalah siswa itu sendiri (Hanson, 2013; Kurniashih et al., 2019; Moog \& Spencer, 2008). Sehingga, peneliti menggunakan model pembelajaran ini sebagai salah satu alternatif untuk diimplementasikan di dalam proses pembelajaran hubungan antar sudut dalam penelitian ini.

Pembelajaran dengan model guided inquiry memiliki sejumlah tahapan, yaitu orientasi, perumusan hipotesis, pendefinisian, eksplorasi, pembuktian, dan perumusan generalisasi (Hartati et al., 2019; Kuhlthau \& Maniotes, 2010; Putra et al., 2016; Yulianti et al., 2020). Selanjutnya, Delclaux dan Saltiel (2013) menyebutkan bahwa dalam proses pembelajaran yang menerapkan model guided inquiry terdiri atas lima tahap, yaitu identifikasi masalah, membuat hipotesis, mengumpulkan data, menganalisis data, dan menarik simpulan. Berdasarkan dua versi mengenai tahapan pembelajaran yang menerapkan model guided inquiry, dapat ditarik suatu simpulan bahwa tahapan pembelajaran menurut model tersebut dimulai dengan menyajikan masalah, mencermati masalah, mengajukan dugaan awal, mengumpulkan data untuk memverifikasi permasalahan, menguji data, dan diakhiri dengan membuat simpulan. Tahapan inilah yang kemudian dijadikan acuan dalam penelitian ini.

Pembelajaran yang mengimplementasikan model guided inquiry memiliki karakteristik, yaitu menekankan aktivitas pembelajaran yang memberikan kesempatan kepada siswa untuk menyelidiki dan menemukan suatu konsep sehingga melalui aktivitas tersebut sikap percaya diri siswa dapat berkembang dan guru hanya berperan sebagai fasilitator dan motivator dalam proses belajar siswa (Kuhlthau \& Maniotes, 2010; Kuhlthau et al., 2015; Yumiati \& Noviyanti, 2017). Selain itu, pembelajaran dengan model guided inquiry juga dapat mengembangkan kemampuan intelektual sebagai proses mental dan seluruh aktivitas pembelajaran dengan model guided inquiry melibatkan seluruh kemampuan siswa dalam melakukan penyelidikan secara sistematis (FitzGerald \& Garrison, 2016; Kuhlthau \& Maniotes, 2010; Kuhlthau et al., 2015).

Berdasarkan paparan mengenai permasalahan siswa dalam pembelajaran hubungan antar sudut dan potensi dari model guided inquiry, mengimplementasikan model pembelajaran guided inquiry dinilai dapat mendukung 
guru dalam memfasilitasi pembelajaran hubungan antar sudut. Penelitian terdahulu telah banyak dilakukan untuk menyelidiki implementasi dari model guided inquiry dalam pembelajaran matematika. Akan tetapi, penelitian tersebut masih berfokus pada hasil akhir, seperti implementasi model ini memberikan dampak hard skills dan soft skills siswa (misalnya, Gunur et al., 2019; Kuhlthau \& Maniotes, 2010; Kuhlthau et al., 2015; Yumiati \& Noviyanti, 2017). Sejumlah peneliti lain juga mengkaji tentang pengembangan kemampuan intelektual sebagai proses mental dan kemampuan menyelidiki secara sistematis melalui model guided inquiry (misalnya, FitzGerald \& Garrison, 2016; Kuhlthau \& Maniotes, 2010; Kuhlthau et al., 2015). Selain itu, beberapa penelitian terdahulu juga telah dilakukan dengan fokus pada pemanfaatan model tersebut sebagai basis untuk mengembangkan suatu perangkat pembelajaran matematika (misalnya, Budhi, 2018; Nuriyatin \& Hartono, 2016; Rochana, 2016). Namun demikian, masih sedikit penelitian yang difokuskan pada mengkaji secara komprehensif terhadap proses pemahaman siswa pada materi hubungan antar sudut dalam pembelajaran yang menerapkan model guided inquiry. Oleh karena itu, penelitian ini berusaha untuk menggali dan memberikan gambaran tentang proses pembelajaran hubungan antar sudut yang menggunakan model guided inquiry dan proses siswa dalam membangun pemahamannya terhadap apa yang sedang mereka pelajari.

\section{METODE}

Metode penelitian yang digunakan pada penelitian ini adalah deskriptif dengan pendekatan kualitatif. Dalam bidang pendidikan, metode kualitatif deskriptif tersebut merupakan metode yang tepat untuk mendeskripsikan kemampuan siswa, perilaku siswa, keadaan lingkungan sekolah, atau proses pembelajaran (Bogdan \& Biklen, 1997; Fraenkel et al., 2012; Hussain, 2015; Prahmana, 2017). Pada penelitian ini dideskripsikan proses pembelajaran yang menggunakan model guided inquiry pada materi hubungan antar sudut.

Implementasi pembelajaran hubungan antar sudut menggunakan model pembelajaran guided inquiry dilaksanakan di SMP Negeri 3 Bantul, Daerah Istimewa Yogyakarta pada bulan Februari hingga Maret 2020 dengan subjek penelitian yaitu 32 siswa kelas VII E. Penelitian ini dilakukan dalam tiga pertemuan tatap muka di kelas, yang mana pertemuan pertama dan kedua merupakan implementasi model pembelajaran hubungan antar sudut kemudian pertemuan ketiga merupakan evaluasi hasil belajar. Tabel 1 merupakan rangkuman aktivitas penelitian dan jadwal kegiatannya.

Tabel 1. Jadwal dan deskripsi aktivitas penelitian

\begin{tabular}{ll}
\hline Hari/Tanggal & Aktivitas \\
\hline Selasa, 25 Februari 2020 & a. Menentukan besar sudut yang dibentuk oleh jarum jam \\
& b. Menentukan jenis-jenis sudut \\
& c. Menentukan sudut berpenyiku \\
& d. Menentukan sudut berpelurus dan sudut bertolak belakang \\
& e. Mengerjakan soal latihan Lembar Aktivitas Siswa (LAS) 1 \\
Jumat, 27 Februari 2020 & a. Menentukan hubungan antar sudut pada dua garis sejajar \\
Selasa, 3 Maret 2020 & b. Mengerjakan soal latihan LAS \\
\hline
\end{tabular}

Selama proses pembelajaran, terdapat seorang observer yang bertugas mengobservasi proses pembelajaran, mengklarifikasi karakteristik, dan prinsip model pembelajaran guided inquiry yang telah diimplementasikan di kelas berdasarkan lembar observasi yang telah didesain menggunakan format daftar cek (checklist) dan isian singkat deskripsi pembelajaran. Adapun sejumlah hal yang diobservasi pada proses pembelajaran di kelas, meliputi kegiatan inti yang berfokus pada aktivitas pengajaran materi hubungan antar sudut menggunakan sintaks atau tahapantahapan pada model pembelajaran guided inquiry. Selanjutnya, peneliti bertindak sebagai guru model dalam proses pembelajaran di kelas dan observer merupakan kolega dari peneliti. Terakhir, seluruh proses pembelajaran dideskripsikan untuk memberikan gambaran secara keseluruhan tentang proses pembelajaran hubungan antar sudut yang menggunakan model guided inquiry.

Data aktivitas siswa selama proses pembelajaran dikumpulkan dalam bentuk rekaman audio dan video, foto serta lembar aktivitas siswa. Data yang dikumpulkan dibagi menjadi dua macam, yaitu data kuantitatif berupa hasil jawaban siswa yang diperoleh dari hasil evaluasi akhir pembelajaran dan data kualitatif berupa transkrip dialog diskusi dan deskripsi proses pembelajaran yang diperoleh dari hasil rekaman audio, video, dan foto kegiatan 
pembelajaran. Seluruh data yang dikumpulkan kemudian dianalisis dengan cara mereduksi, menampilkan dan menyimpulkan data, setelah itu ditulis dalam bentuk narasi deskriptif (Fraenkel et al., 2012; Maisyarah \& Prahmana, 2020; Prahmana, 2017). Adapun data yang direduksi adalah data video dan foto selama proses pembelajaran, yang diamati, dikaji, dan dianalisis oleh dua orang, yaitu mahasiswa dan dosen pembimbing penelitiannya. Selanjutnya, data yang ditampilkan berfokus pada data yang diperlukan untuk menampilkan proses pembelajaran di kelas dan simpulan dilakukan untuk memenuhi tujuan penelitian. Setelah itu, proses analisis dalam bentuk narasi deskriptif dilakukan untuk mendeskripsikan proses pembelajaran menggunakan model pembelajaran guided inquiry. Terakhir, hasil evaluasi pembelajaran digunakan sebagai salah satu indikator keberhasilan implementasi model pembelajaran quided inquiry dalam memfasilitasi pemahaman siswa terhadap hubungan antar sudut.

\section{HASIL PENELITIAN}

\section{Pertemuan Pertama}

Pertemuan pertama diawali dengan berdoa dan dilanjutkan dengan melakukan presensi siswa, memberikan apersepsi, menyampaikan tujuan pembelajaran, dan menyampaikan aktivitas yang akan dilakukan oleh siswa selama proses pembelajaran. Pada pertemuan pertama terdapat empat aktivitas pembelajaran yang dilakukan oleh siswa, yaitu pertama, menentukan besar sudut yang dibentuk oleh jarum jam; kedua, menentukan jenis-jenis sudut; ketiga, menentukan karakteristik dari sudut berpenyiku; dan keempat, menentukan karakteristik dari sudut berpelurus dan sudut bertolak belakang. Apersepsi yang dilakukan oleh guru adalah mengajukan tanya jawab dengan siswa sebagaimana disajikan pada Dialog 1.

\section{Dialog 1}

Guru : “Coba sebutkan benda apa saja yang membentuk sudut?"

Siswa 1 : "Pojok papan tulis"

Guru : "Ya benar, apa lagi yang lain?"

Siswa 2 : "Pojok meja” (sambil menunjukkan)

Guru : "Ya benar, objek lain lagi di jarum jam, dan masih banyak lagi objek yang lain ya."

Berdasarkan tanya jawab pada Dialog 1 , siswa dapat mengetahui benda apa saja yang membentuk sudut. Misalkan pojok papan tulis, pojok meja, jarum jam, dan lain-lain. Guru kemudian membagikan Lembar Aktivitas Siswa (LAS) 1 dan meminta siswa membentuk kelompok secara mandiri, yang mana dalam satu kelompok terdiri atas 4 atau 5 orang siswa. Karena kelas VII E pada hari pertama terdiri atas 30 orang siswa, berarti terdapat tujuh kelompok yang terbentuk. Setelah membagikan LAS 1, guru kemudian meminta setiap kelompok untuk mendiskusikan cara menyelesaikan permasalahan yang terdapat dalam LAS 1. Siswa diperbolehkan untuk bertanya apabila terdapat sesuatu yang belum jelas dalam soal atau dalam LAS. Berikut deskripsi keempat aktivitas pada pertemuan pertama.

\section{Aktivitas 1: Menentukan besar sudut yang terbentuk oleh jarum jam}

Aktivitas pertama yaitu menentukan besar sudut yang terbentuk oleh jarum jam. Tujuan dari aktivitas ini adalah memfasilitasi siswa agar memahami tentang bagaimana menentukan besar sudut yang terbentuk oleh jarum jam dan jarum menit. Masalah yang disajikan dalam LAS 1 sebagai fasilitas yang diberikan guru kepada siswa untuk mencapai tujuan tersebut disajikan pada Gambar 1.

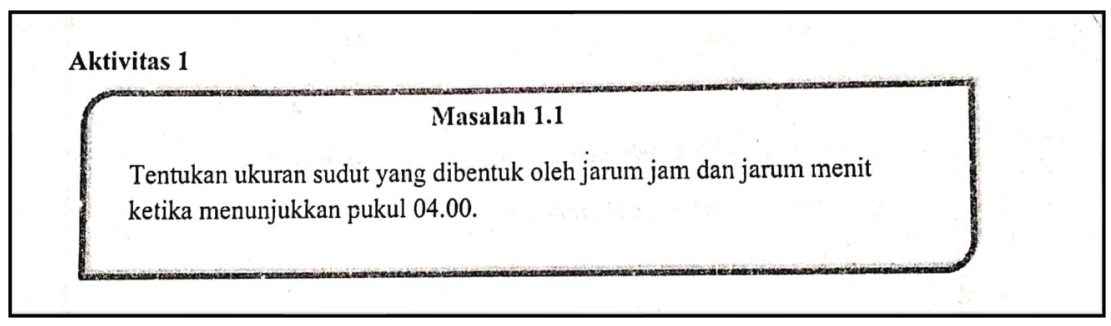

Gambar 1. Lembar Aktivitas Siswa (LAS) 1 Aktivitas 1

Selama proses pengerjaan LAS 1 Aktivitas 1, terjadi diskusi menarik antar siswa di dalam kelompoknya yang berujung pada mengajukan pertanyaan kepada guru. Selanjutnya, guru menjawab sejumlah pertanyaan dari salah 
satu kelompok siswa terkait LAS 1 (lihat Gambar 2). Aktivitas diskusi antara siswa dan guru seperti ini dikarenakan tidak terjadi kesepakatan antar anggota kelompok terhadap jawaban dari masing-masing siswa. Adapun diskusi antara salah satu siswa dalam kelompok tersebut dengan guru disajikan pada Dialog 2.

Dialog 2

Siswa 3 : "Bu saya mau bertanya."

Guru : "Ya mau tanya yang mana?"

Siswa 3 : "Berarti ini 120 ya?"

Guru : :Kok bisa. Di sini sudah $\frac{4}{12}$ lalu kalo pembimbilangnya jadi 1 penyebutnya berapa?”

Siswa 3 : "120 Bu?"

Guru : "Bukan, dari $\frac{4}{12}$ disederhanakan jadi 1 per?"

Siswa 3 : "Oh 3 Bu"

Guru : "Ya benar. Dilanjutkan mengerjakannya"

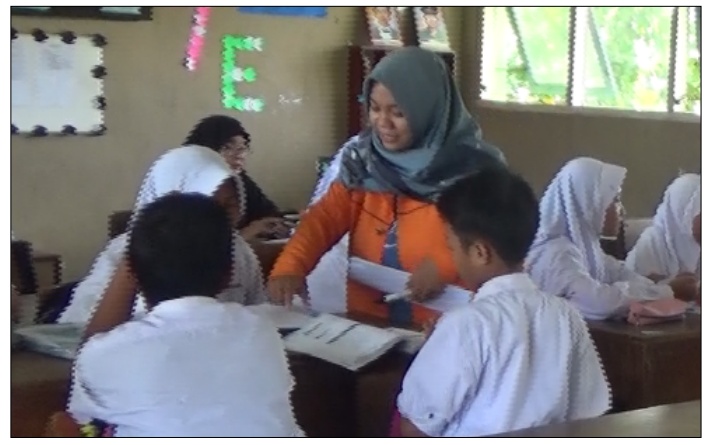

Gambar 2. Siswa bertanya kepada guru mengenai LAS 1 Aktivitas 1

Diskusi pada Dialog 2 menunjukkan bahwa guru bertindak sebagai fasilitator dalam menggiring jawaban siswa dengan pertanyaan-pertanyaan yang menuntun siswa ke jawaban yang diinginkan. Proses ini ditujukan agar siswa tidak mendapatkan pengetahuan secara langsung atau agar siswa mampu mengonstruksi sendiri pemahaman mereka. Proses seperti ini merepresentasikan salah satu karakteristik dalam pelaksanaan proses pembelajaran yang menggunakan model guided inquiry (Hartati et al., 2019; Kuhlthau \& Maniotes, 2010; Putra et al., 2016). Selanjutnya, Gambar 3 menunjukkan bahwa pertama siswa membuat gambar jam kemudian diberikan gambar jarum yang menunjukkan jam dan menit pada pukul 04.00. Setelah itu dari jarum tersebut dapat ditentukan sudut yang terbentuk adalah $\frac{4}{12}$ kemudian disederhanakan menjadi $\frac{1}{3}$ putaran penuh. Hasil penyederhanaan dikalikan dengan sudut satu putaran penuh sehingga diperoleh besar sudut yang terbentuk yaitu $120^{\circ}$. Pada Aktivitas 1 , semua kelompok telah memahami cara menentukan besar sudut yang terbentuk oleh jarum jam dan menit.

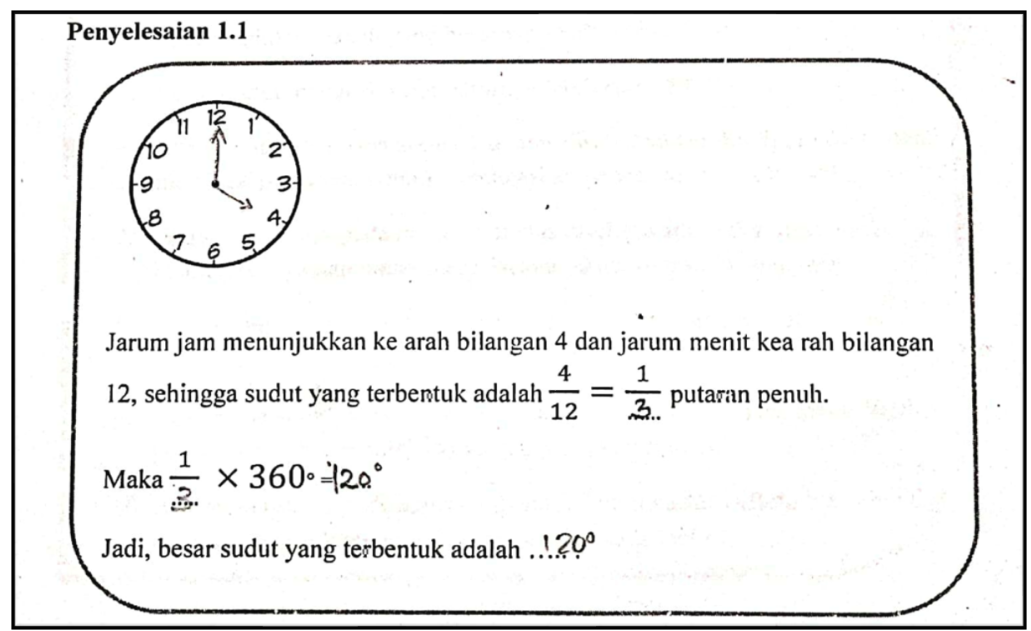

Gambar 3. Jawaban siswa pada LAS 1 Aktivitas 1 


\section{Aktivitas 2: Menentukan jenis-jenis sudut}

Aktivitas kedua yaitu menentukan jenis-jenis sudut. Tujuan dari aktivitas ini adalah memfasilitasi siswa untuk memahami tentang jenis-jenis sudut dan karakteristik dari setiap jenis sudut yang ada. Gambar 4 menunjukkan LAS 1 Aktivitas 2, di mana pada aktivitas ini siswa diminta untuk mengukur besar sudut menggunakan busur derajat, kemudian menentukan jenis sudutnya. Pada aktivitas ini, beberapa siswa masih mengalami kebingungan dalam mengukur sudut.

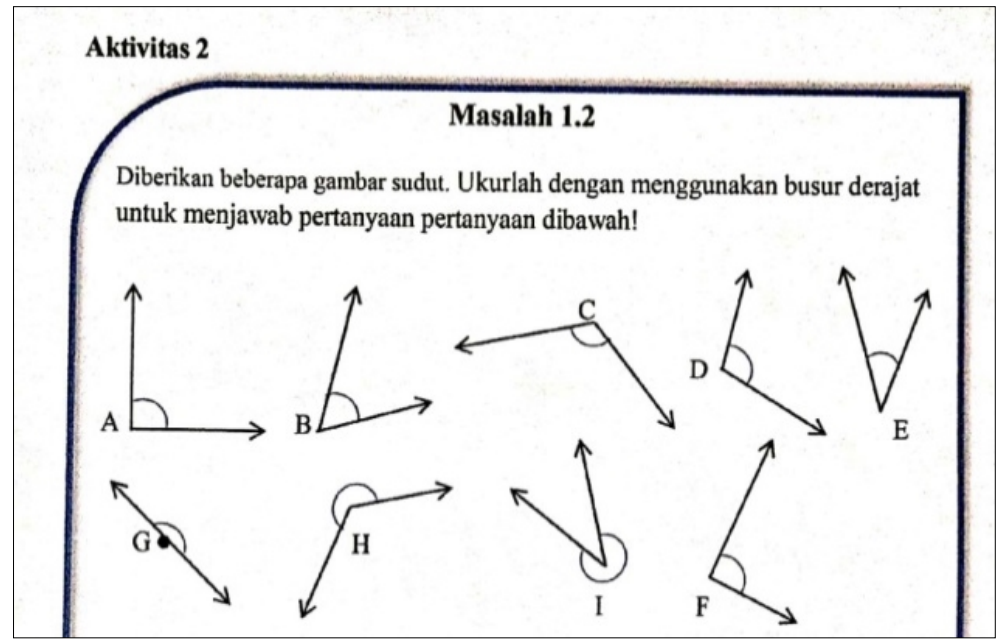

Gambar 4. Lembar Aktivitas Siswa (LAS) 1 Aktivitas 2

Pada proses penyelesaian masalah terkait cara mengukur sudut, terjadi diskusi menarik antara siswa dan guru mengenai sudut putaran penuh. Gambar 5 menunjukkan antusiasme siswa dalam menyampaikan pertanyaanpertanyaan terkait aktivitas yang terdapat dalam LAS yang diberikan.

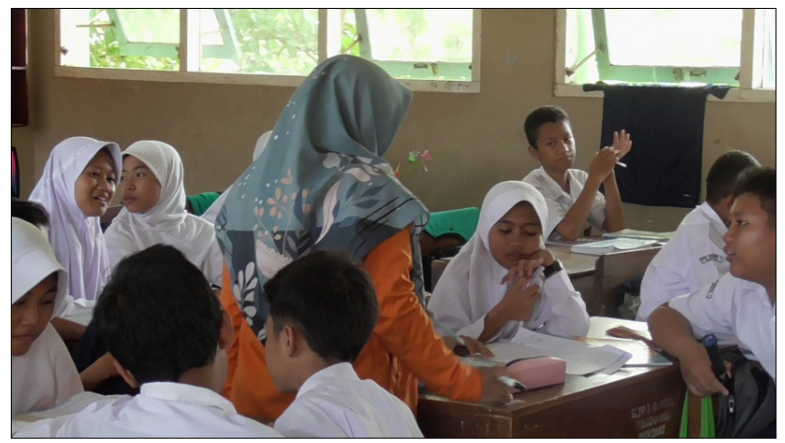

Gambar 5. Siswa bertanya cara mengukur sudut

Pertanyaan-pertanyaan yang diberikan guru ditujukan untuk memandu pemahaman siswa terkait konten materi tersebut. Dialog 3 menyajikan penggalan diskusi antara guru dan siswa tentang mengukur sudut.

\section{Dialog 3}

Siswa 4 : "Bu, saya mau bertanya"

Guru : :Ya mau tanya yang mana?"

Siswa 4 : "Yang ini benar tidak, Bu?"

Guru : "Kan yang diukur yang ini (sambil menunjuk $\angle$ I). Jadi sudut 1 putaran penuh di kurangi dengan sudut yang sudah kamu hitung itu."

Siswa 4 : “360 dikurang 50 ya, Bu?"

Guru : "Iya benar"

Selanjutnya, Gambar 6 menampilkan hasil jawaban siswa atas soal yang diberikan pada LAS 1 Aktivitas 2 (soal lihat Gambar 4). Siswa diminta untuk menentukan besar sudut pada gambar sudut yang ada dalam LAS 1 Aktivitas 2. Hasilnya beberapa kelompok berhasil menjawab dengan tepat tetapi ada juga kelompok yang menjawab dengan tidak tepat. 


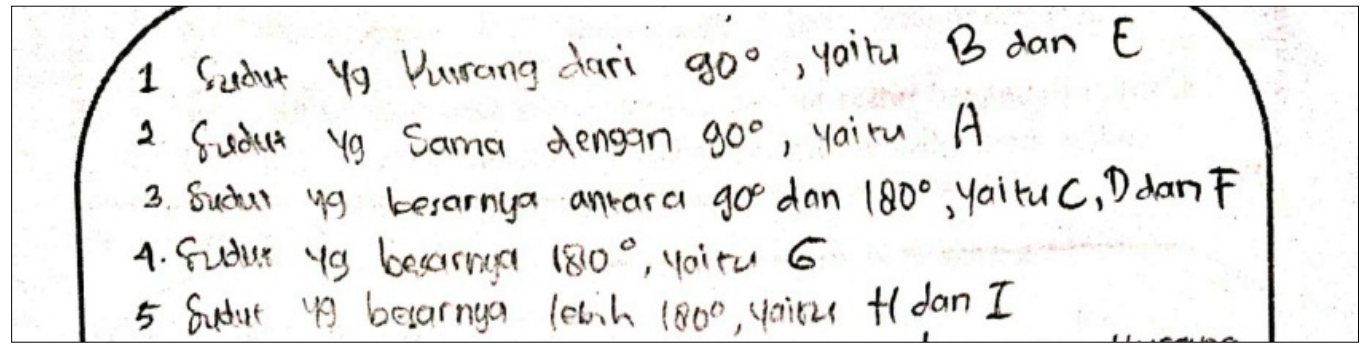

Gambar 6. Hasil pekerjaan siswa dalam menjawab soal pada LAS 1 Aktivitas 2

Aktivitas 3: Menentukan karakteristik sudut berpenyiku

Aktivitas 3 yaitu menentukan sudut berpenyiku. Aktivitas ini bertujuan untuk memfasilitasi siswa dalam memahami tentang sudut berpenyiku.

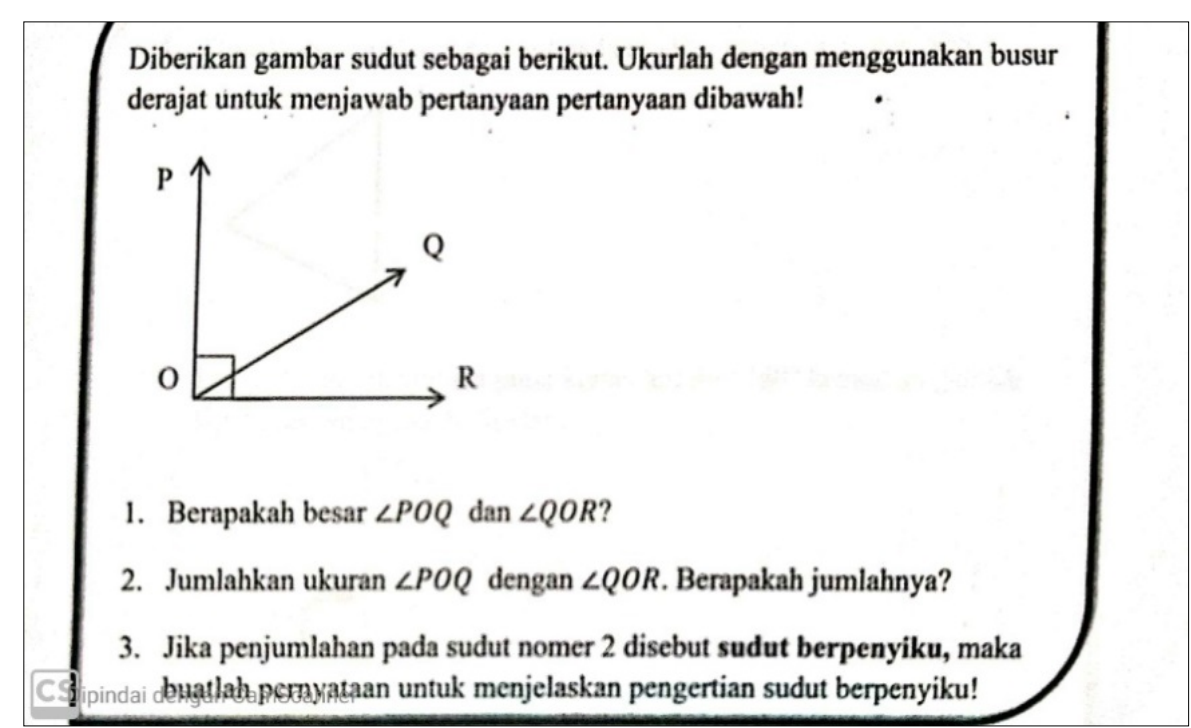

Gambar 7. Lembar Aktivitas Siswa (LAS) 1 Aktivitas 3

Pada LAS 1 Aktivitas 3, siswa diberikan gambar sudut, kemudian siswa diminta mengukur besar sudut yang ada di gambar tersebut menggunakan busur derajat dan menentukan karakteristik dari sudut berpenyiku, seperti tampak pada Gambar 7. Selanjutnya, pada Gambar 8 dapat dilihat bahwa kelompok 1 dapat menjawab soal dengan benar. Pertama siswa mengukur sudut menggunakan busur derajat. Kemudian menjumlahkan sudut yang sudah dihitung hingga diperoleh hasil $90^{\circ}$. Setelah itu siswa mendefinisikan sudut berpenyiku.

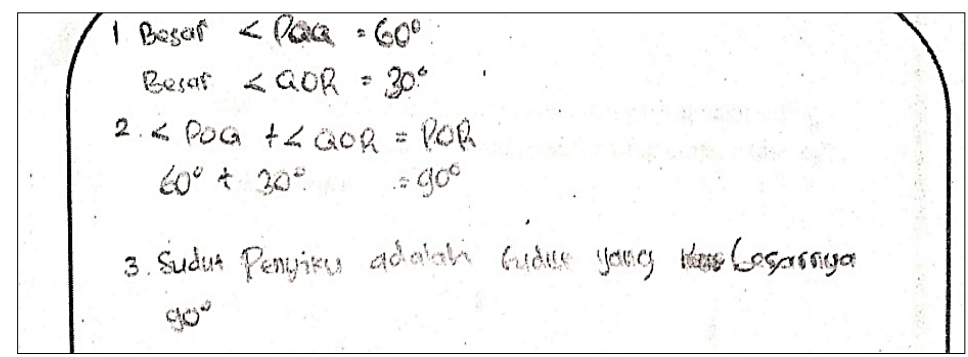

Gambar 8. Hasil pekerjaan siswa dalam menjawab soal pada LAS 1 Aktivitas 3

Aktivitas 4: Menentukan karakteristik sudut berpelurus dan sudut bertolak belakang

Aktivitas 4 yaitu menentukan sudut berpelurus dan sudut bertolak belakang. Aktivitas ini bertujuan untuk memfasilitasi siswa dalam memahami tentang makna dan karakteristik dari sudut berpelurus dan sudut bertolak belakang. Gambar 9 (a) merupakan LAS 1 Aktivitas 4, di mana melalui aktivitas tersebut siswa diminta untuk membentuk dua garis yang saling berpotongan dari dua segitiga. Selanjutnya, Gambar 9 (b) merupakan jawaban siswa dalam menyelesaikan soal LAS 1 Aktivitas 4. Siswa menjawab dengan cara terlebih dahulu menggambar 
PYTHAGORAS: Jurnal Pendidikan Matematika, 15 (2), 2020 - 144

Sundari Gita Pertiwi, Rully Charitas Indra Prahmana

segitiga, kemudian memutar segitiga sebesar $180^{\circ}$ sehingga terbentuk dua garis yang saling berpotongan dan terbentuk empat sudut. Siswa kemudian mengukur besar keempat sudut tersebut dengan busur derajat. Dari pengukuran tersebut siswa dapat menyebutkan makna dan karakteristik dari sudut berpelurus dan sudut bertolak belakang.

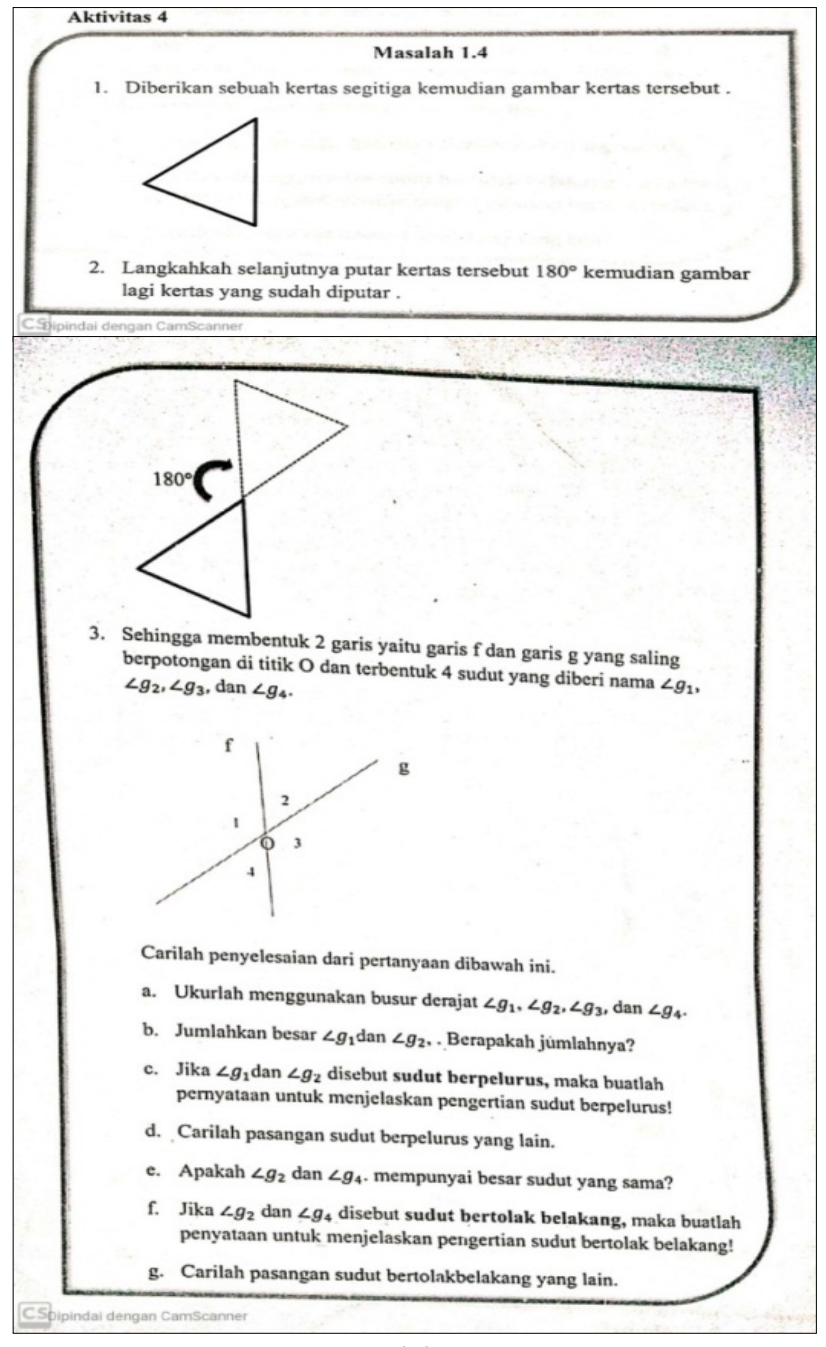

(a)

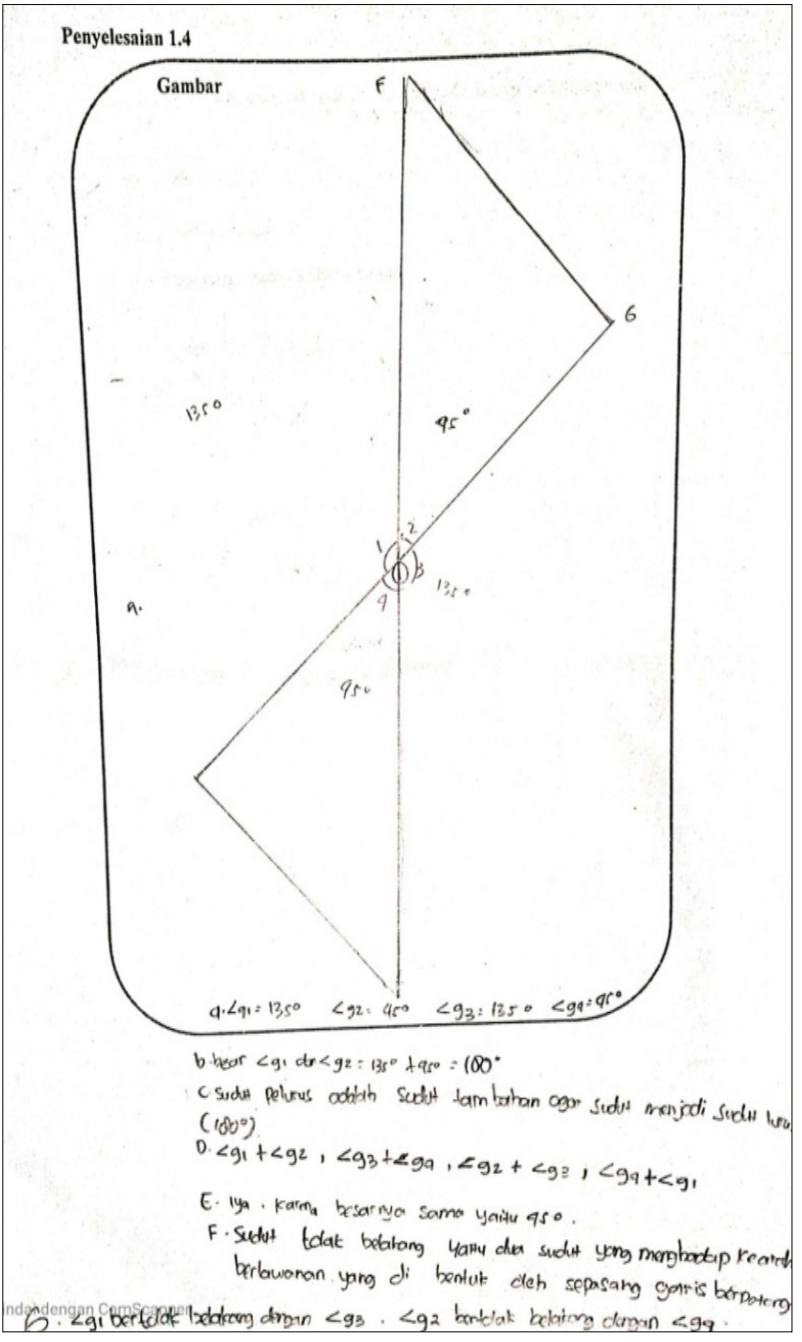

(b)

Gambar 9. (a) Lembar Aktivitas Siswa (LAS) 1 Aktivitas 4; (b) Hasil pekerjaan salah satu siswa dalam menjawab soal pada LAS 1 Aktivitas 4

\section{Aktivitas 5: Mempresentasikan hasil pengerjaan LAS}

Pada Aktivitas 5, siswa mempresentasikan hasil pengerjaan LAS di depan kelas (lihat Gambar 10). Guru menawarkan kepada siswa yang berkenan untuk ke depan kelas dan menuliskan hasil pengerjaan LAS, karena tidak ada yang berkenan, maka guru menunjuk dua siswa sebagai perwakilan dari suatu kelompok.

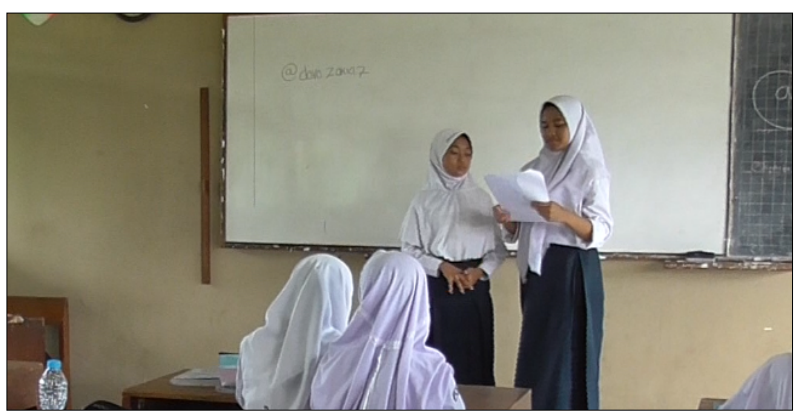

Gambar 10. Siswa mempresentasikan hasil pengerjaan LAS 


\section{Pertemuan Kedua}

Pertemuan kedua diawali dengan berdoa dan dilanjutkan dengan melakukan presensi siswa dan guru memberikan apersepsi dan menyampaikan tujuan pembelajaran. Pada pertemuan kedua ini terdiri atas dua aktivitas, yaitu menentukan sudut-sudut pada dua garis sejajar dan mempresentasikan hasil pengerjaan LAS. Guru membagi siswa secara acak tanpa mempertimbangkan kemampuan siswa ke dalam beberapa kelompok yang terdiri dari tiga atau empat siswa. Guru kemudian membagikan LAS 2 dan meminta siswa untuk mendiskusikan permasalahan yang ada dalam LAS 2 serta menyelesaikan permasalahan tersebut. Berikut deskripsi aktivitas pada pertemuan kedua.

\section{Aktivitas 1: Menentukan sudut-sudut pada dua garis sejajar}

Aktivitas 1 pada pertemuan kedua yaitu menentukan sudut-sudut yang terbentuk pada dua garis sejajar yang dipotong oleh suatu garis transversal. Aktivitas ini bertujuan untuk memfasilitasi siswa dalam memahami tentang hubungan antar sudut yang terbentuk akibat dua garis sejajar di potong oleh garis lain.

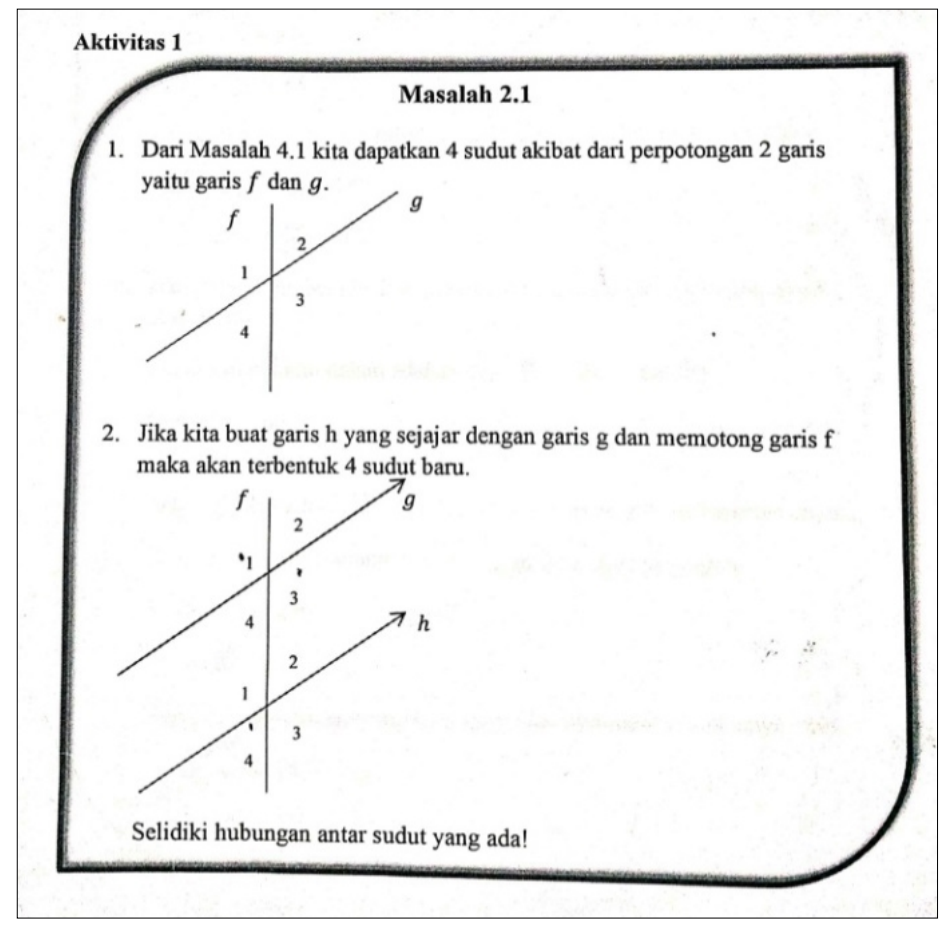

Gambar 11. Lembar Aktivitas Siswa (LAS) 2 Aktivitas 1

Gambar 11 merupakan gambar LAS 2 Aktivitas 1, di mana pada LAS tersebut siswa diminta untuk menyelidiki hubungan antar sudut yang terbentuk akibat dua garis yang di potong oleh garis lain.

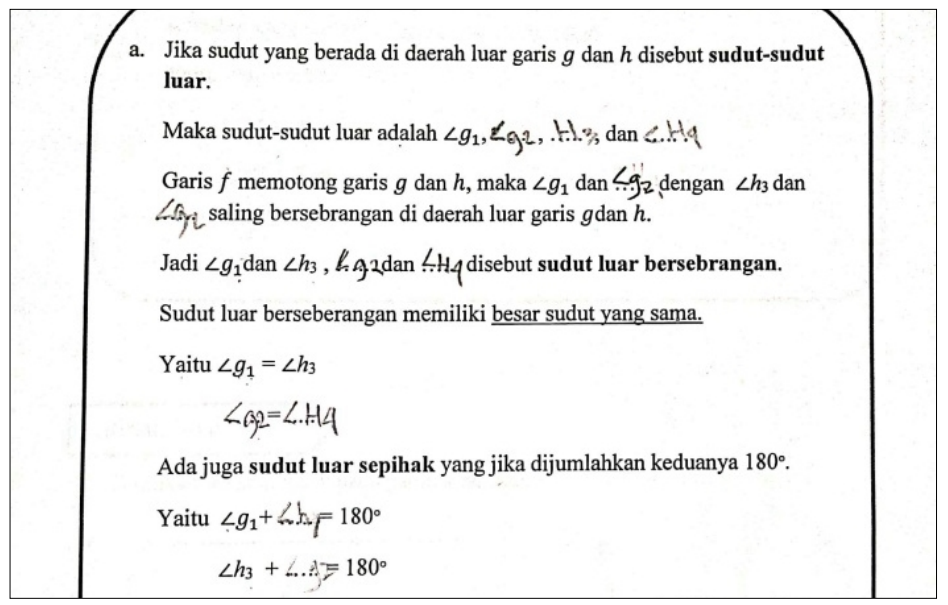

Gambar 12. Hasil pekerjaan siswa dalam menjawab soal pada LAS 2 Aktivitas 1 
Pada Gambar 12 dapat dilihat bahwa siswa telah menjawab dengan benar soal yang ada dalam LAS 2 Aktivitas 1. Pertama siswa menyebutkan sudut-sudut luar, yaitu sudut luar berseberangan dan sudut luar sepihak. Kemudian siswa menyebutkan bahwa pasangan sudut luar berseberangan memiliki ciri yaitu sudut yang memiliki besar sudut yang sama besar. Selanjutnya siswa menyebutkan sepasang sudut luar sepihak dengan ciri bahwa sudut luar sepihak merupakan sudut yang apabila dijumlahkan hasilnya $180^{\circ}$.

\section{Aktivitas 2: Mempresentasikan hasil pengerjaan LAS}

Aktivitas 2 siswa mempresentasikan hasil pengerjaan LAS 2 di depan kelas. Guru menawarkan kepada siswa yang berkenan untuk maju ke depan kelas dan mempresentasikan hasil pengerjaan LAS 2 bersama dengan kelompoknya. Karena tidak ada siswa yang berkenan, kemudian guru menunjuk salah satu siswa untuk maju ke depan bersama dengan kelompoknya mempresentasikan hasil pengerjaan LAS 2.

\section{Pertemuan Ketiga}

Pertemuan ketiga diawali dengan doa, guru melakukan presensi siswa, memberikan apersepsi, dan menyampaikan tujuan pembelajaran. Aktivitas awal sebelum evaluasi akhir pembelajaran ini merupakan aktivitas rutin sebelum proses pembelajaran. Adapun aktivitas presensi ditujukan untuk mengetahui siswa yang tidak hadir pada pertemuan ketiga ini, apersepsi yang dilakukan lebih kepada reviu dua aktivitas pembelajaran sebelumnya, dan penjelasan tujuan pembelajaran dilakukan untuk menjelaskan kepada siswa terkait tujuan evaluasi akhir pembelajaran yang hendak dilakukan. Selanjutnya, pada pertemuan ketiga ini, siswa diberikan soal evaluasi untuk melihat pemahaman siswa setelah implementasi pembelajaran dengan model pembelajaran guided inquiry. Guru memberikan waktu 10 menit kepada siswa untuk menyiapkan diri dan membaca kembali materi yang telah dipelajari. Soal evaluasi terdiri atas empat butir soal uraian dengan cakupan materi sesuai dengan yang telah siswa pelajari pada dua pertemuan pembelajaran sebelumnya. Waktu pengerjaan soal evaluasi adalah 40 menit dan dikerjakan secara mandiri (lihat Gambar 13).
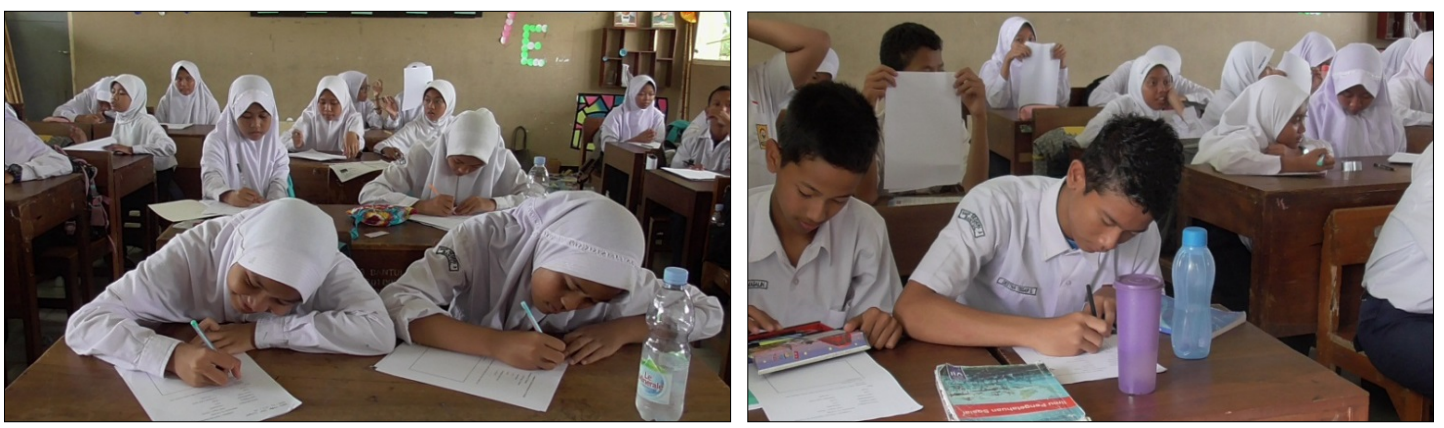

Gambar 13. Siswa mengerjakan soal evaluasi

\section{Analisis data hasil pengerjaan soal evaluasi}

Evaluasi dilakukan pada pertemuan ketiga dan digunakan untuk mengetahui hasil belajar atau pemahaman siswa mengenai hubungan antar sudut. Hasil evaluasi tersebut disajikan dalam Gambar 14.

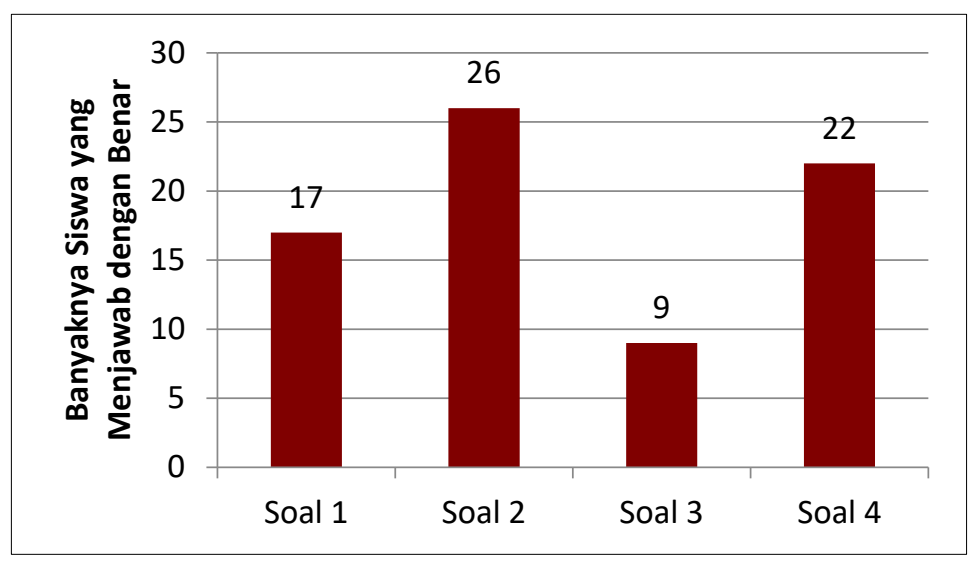

Gambar 14. Capaian hasil belajar atau pemahaman siswa mengenai hubungan antar sudut 
Gambar 14 menunjukkan data bahwa soal yang paling banyak dikerjakan secara benar oleh siswa adalah soal nomor 2. Adapun soal nomor 3 merupakan soal yang paling sedikit dikerjakan secara benar oleh siswa. Terdapat beberapa kesalahan yang dilakukan atau kesulitan yang dialami oleh siswa dalam menyelesaikan soal-soal uraian tersebut, yaitu siswa kurang teliti dalam membaca pertanyaan yang terdapat dalam soal, siswa kurang fokus dalam mengerjakan soal yang ada, dan siswa masih bingung dalam melakukan penjumlahan, pengurangan, perkalian, dan pembagian aljabar satu variabel. Secara keseluruhan, hasil yang diperoleh siswa pada evaluasi ini menunjukkan bahwa implementasi model guided inquiry pada pembelajaran hubungan antar sudut mampu memfasilitasi lebih dari $50 \%$ siswa dalam menyelesaikan $75 \%$ soal evaluasi akhir dengan benar. Ini artinya lebih dari 50\% siswa telah memahami konsep hubungan antar sudut dengan mampu menyelesaikan $75 \%$ soal evaluasi akhir dengan benar.

\section{PEMBAHASAN}

Penelitian ini berusaha untukmengungkapkan proses pembelajaran hubungan antar sudut yang menerapkan model guided inquiry melalui aktivitas pembelajaran tertentu. Pada pertemuan pertama, siswa diminta untuk mengaitkan pembelajaran hubungan antar sudut dengan kehidupan sehari hari. Kegiatan ini merupakan tahapan awal dalam model guided inquiry yaitu merumuskan masalah (Kuhlthau \& Maniotes, 2010; Putra et al., 2016). Guru memberikan pertanyaan agar siswa dapat berpikir dan menemukan jawaban yang tepat. Tahap selanjutnya yaitu merumuskan hipotesis. Siswa memiliki jawaban sementara atas masalah yang diberikan guru. Kemudian, guru memberikan kesempatan kepada siswa untuk menyampaikan gagasan yang berkaitan dengan pertanyaan yang diberikan guru. Pada tahap ini, beberapa siswa masih mengalami kebingungan saat diminta menjawab pertanyaan yang diberikan guru. Hal ini disebabkan guru tidak memberikan pengajaran secara langsung, namun dengan pertanyaan-pertanyaan yang memandu siswa dalam menyelesaikan permasalahan yang diberikan sebagai bentuk dari sintaks model guided inquiry (Kuhlthau et al., 2015).

Tahap ketiga yaitu merancang dan melakukan eksperimen. Sebelum mengerjakan setiap aktivitas yang difasilitasi oleh guru, siswa harus mencermati perintah dan langkah-langkah yang ada. Tahap ini melatih siswa untuk melibatkan ketrampilan siswa dalam berpikir kreatif. Namun beberapa siswa tidak mengikuti langkah yang ada, sehingga merasa kesulitan dan bertanya kepada guru. Tahap selanjutnya yaitu mengumpulkan data dan mengolah data. Siswa mengumpulkan data dari langkah-langkah yang sudah dilakukan oleh siswa pada tahap sebelumnya. Pada kegiatan ini guru berperan mengajukan pertanyaan-pertanyaan yang dapat mendorong siswa untuk mencari informasi yang dibutuhkan, sebagaimana dicontohkan pada beberapa penelitian sebelumnya (misalnya, Hanson, 2013). Data yang diperoleh digunakan untuk mengambil kesimpulan (FitzGerald \& Garrison, 2016).

Pada saat siswa mengerjakan LAS 1 Aktivitas 1 (lihat Gambar 1) dan melukis jarum jam dan jarum menit yang ditanyakan, peneliti berkeliling kelas mengecek pekerjaan dan memberikan bantuan kepada siswa yang mengalami kesulitan. Salah satu kesulitan yang didapat siswa masih bingung untuk menyederhanakan pecahan (lihat Dialog 1). Kemudian, pada LAS 1 Aktivitas 2 (lihat Gambar 4) siswa diberikan permasalahan mengenai jenis-jenis sudut. Siswa diminta melakukan pengukuran setiap gambar sudut. Pada aktivitas ini, siswa mengalami kesulitan dalam mengukur sudut yang lebih dari $180^{\circ}$. Jadi, beberapa siswa masih melakukan kesalahan dalam mengategorikan setiap jenis sudut. Namun demikian, pada akhirnya siswa dapat menarik simpulan dengan menjelaskan karakteristik dari jenis-jenis sudut dengan benar. Kondisi seperti ini juga dijumpai oleh sejumlah peneliti sebelumnya (misalnya, Clements \& Sarama, 2011; Novita et al., 2018; Panaoura, 2014; Rofii etal., 2018). Hal ini disebabkan siswa sudah terbiasa dengan pengajaran secara langsung, sehingga materi matematika sudah menjadi bahan jadi, bukan dicari sendiri oleh siswa. Selanjutnya, guru mengarahkan siswa untuk mengerjakan LAS 1 Aktivitas 3 (lihat Gambar 7). Pada aktivitas ini, siswa diminta untuk mengukur gambar sudut. Pada aktivitas ini, siswa tidak mengalami kendala dalam mengerjakannya. Siswa sudah bisa mengikuti Aktivitas 3 dengan baik yang ditunjukkan dari simpulan yang diberikan oleh siswa bahwa sudut penyiku adalah sudut jika dijumlahkan besarnya $90^{\circ}$. Setelah mengerjakan Aktivitas 3, siswa melanjutkan proses pembelajaran dengan mengerjakan LAS 1 Aktivitas 4 (lihat Gambar 9 (a)). Pada aktivitas ini, siswa diminta untuk menggambar dua garis yang saling berpotongan dari gambar awal yaitu sebuah segitiga. Kesulitan dalam aktivitas ini adalah menentukan pasangan sudut berpelurus yang lain. Namun untuk simpulan yang diberikan oleh siswa sudah benar, bahwa sudut berpelurus adalah sudut yang jika dijumlahkan besarnya $180^{\circ}$ dan sudut bertolak belakang adalah sudut yang menghadap ke arah yang berbeda yang dibentuk oleh dua garis berpotongan.

Terakhir, guru menawarkan siswa untuk mempresentasikan hasil diskusi mereka secara lisan di depan kelas. Kegiatan ini ditujukan untuk menyamakan persepsi antar siswa terhadap materi yang mereka pelajari. Selain itu, 
aktivitas ini juga dapat dijadikan salah satu alternatif untuk mengidentifikasi pemahaman siswa terhadap konten pembelajaran yang sedang mereka pelajari (Kurniashih et al., 2019; Moog \& Spencer, 2008). Guru bertanya kepada siswa mengenai pembelajaran hari ini, namun siswa sudah paham sehingga tidak ada pertanyaan yang disampaikan kepada guru. Pada pertemuan kedua, seperti pada pertemuan sebelumnya sesuai dengan arahan guru, siswa berdiskusi dengan kelompok yang sudah dibentuk, sedangkan guru berkeliling kelas untuk melihat hasil pekerjaan siswa dan membimbing siswa yang mengalami kesulitan. Guru mengingatkan untuk lebih teliti dalam membaca permasalahan yang diberikan. Kesulitan siswa pada aktivitas ini yaitu kurang teliti dan tidak yakin dengan jawaban. Namun, siswa tidak ada kendala dalam menyimpulkan hubungan antar sudut yang ada. Hasil penelitian ini berkontribusi dalam memberikan deskripsi proses pembelajaran hubungan antar sudut yang menggunakan model pembelajaran guided inquiry, sehingga dapat menambah bukti empiris terhadap implementasi model tersebut yang mampu memberikan pemahaman siswa terhadap suatu topik dalam pembelajaran matematika, sebagaimana telah dilakukan dalam penelitian sebelumnya (misalnya, Kurniashih et al., 2019; Putra et al., 2016; Yumiati \& Noviyanti, 2017).

\section{SIMPULAN}

Model pembelajaran guided inquiry dapat digunakan untuk memberikan pemahaman kepada siswa mengenai konsep hubungan antar sudut. Selanjutnya, aktivitas pembelajaran hubungan antar sudut dilakukan dalam empat tahap. Tahapan pertama merupakan aktivitas siswa dalam mengaitkan pembelajaran hubungan antar sudut dengan kehidupan sehari hari. Aktivitas ini merupakan bagian dari sintaks model guided inquiry, yaitu menyajikan dan mencermati masalah yang dalam hal ini dikaitkan dengan aktivitas sehari-hari siswa. Tahapan kedua yaitu aktivitas siswa dalam merumuskan hipotesis atau dugaan sementara terhadap jawaban pengerjaan soal pada LAS. Hal ini merupakan bagian dari sintaks model guided inquiry, yaitu mengajukan dugaan awal atau hipotesis. Ketiga, tahapan siswa dalam menyelesaikan soal pada LAS yang diberikan, yang merupakan bagian dari sintaks keempat dalam model guided inquiry, yaitu mengumpulkan data untuk memverifikasi permasalahan. Terakhir, tahapan siswa dalam mengumpulkan informasi dari LAS yang diberikan, serta pengetahuan awal yang dimiliki siswa dan mengolahnya untuk menjawab permasalahan yang disajikan pada setiap LAS. Aktivitas terakhir ini merupakan lanjutan dari sintaks model guided inquiry, mulai dari mengumpulkan data untuk memverifikasi permasalahan, menguji data, dan terakhir membuat kesimpulan. Selain itu, pembelajaran dilakukan dalam dua pertemuan dengan beberapa aktivitas yang dapat menuntun siswa untuk menemukan konsep hubungan antar sudut. Terakhir, model pembelajaran guided inquiry tampak berperan dalam membantu siswa dalam memahami konsep hubungan antar sudut yang terlihat dari hasil evaluasi akhir yang dilakukan pada pertemuan ketiga di akhir pembelajaran.

\section{UCAPAN TERIMA KASIH}

Peneliti mengucapkan banyak kepada para siswa di Kelas VII serta para guru di SMP Negeri 3 Bantul. Selanjutnya, peneliti juga mengucapkan terima kasih kepada Universitas Ahmad Dahlan yang terus mendukung peneliti dalam hal penelitian dan publikasi hasil penelitian.

\section{DAFTAR PUSTAKA}

Ananda, R. P., Sanapiah, S., \& Yulianti, S. (2018). Analisis kesalahan siswa kelas VII SMPN 7 Mataram dalam menyelesaikan soal garis dan sudut tahun pelajaran 2018/2019. Media Pendidikan Matematika, 6(2), 79-87. https://doi.org/10.33394/mpm.v6i2.1838

Biber, C.., Tuna, A., \& Korkmaz, S. (2013). The mistakes and the misconceptions of the eighth grade students on the subject of angles. European Journal of Science and Mathematics Education, 1(2), 50-59. https://doi.org/10.30935/scimath/9387

Bogdan, R., \& Biklen, S. K. (1997). Qualitative research for education. Allyn \& Bacon.

Budhi, M. N. C. (2018). Pengembangan perangkat pembelajaran contextual guided inquiry untuk meningkatkan motivasi dan prestasi belajar matematika. Pythagoras: Jurnal Pendidikan Matematika, 13(1), 10-20. https://doi.org/10.21831/pg.v13i1.13512 
Clements, D. H., \& Sarama, J. (2011). Early childhood teacher education: The case of geometry. Journal of Mathematics Teacher Education, 14(2), 133-148. https://doi.org/10.1007/s10857-011-9173-0

Delclaux, M., \& Saltiel, E. (2013). An evaluation of local teacher support strategies for the implementation of inquiry-based science education in French primary schools. Education 3-13, 41(2), 138-159. https://doi.org/10.1080/03004279.2011.564198

Fabiyi, T. R. (2017). Geometry concepts in mathematics perceived difficult to learn by senior secondary school students in Ekiti State, Nigeria. IOSR Journal of Research \& Method in Education (IOSR-JRME), 7(1), 83-90. https://doi.org/10.9790/7388-0701018390

FitzGerald, L., \& Garrison, K. L. (2016). Investigating the guided inquiry process. In S. Kurbanoğlu, J. Boustany, S. Špiranec, E. Grassian, D. Mizrachi, L. Roy, \& T. Çakmak (Eds.), Information literacy: Key to an inclusive society: 4th European Conference, European Conference on Information Literacy (Vol. 676, pp. 667-677). Springer. https://doi.org/10.1007/978-3-319-52162-6_65

Fraenkel, J. R., Wallen, N. E., \& Hyun, H. H. (2012). How to design and evaluate research in education (8th ed.). McGraw-Hill.

Gunur, B., Lalus, E., \& Ali, F. A. (2019). Students' understanding of mathematical concepts through the guided inquiry learning. Edumatica: Jurnal Pendidikan Matematika, 9(2), 34-40. https://doi.org/10.22437/edumatica.v9i02.7260

Hadi, S., Retnawati, H., Munadi, S., Apino, E., \& Wulandari, N. F. (2018). The difficulties of high school students in solving higher-order thinking skills problems. Problems of Education in the 21st Century, 76(4), 520-532. https://dx.doi.org/10.33225/pec/18.76.520

Hanson, D. M. (2013). POGIL: Instructor's guide to process-oriented guided-inquiry learning. Pacific Crest. https://pcrest.com/research/POGIL_Instructor_Guide2014.pdf

Hartati, H., Setyasto, N., Sutikno, P. Y., \& Renggani, R. (2019). Peningkatan keterampilan profesional guru-guru SD gugus Ganesha Windusari Magelang melalui pelatihan implementasi model inquiry based learning (IBL) bermuatan six pillars of character. Jurnal Panjar: Pengabdian Bidang Pembelajaran, 1(1), 9-16. https://journal.unnes.ac.id/sju/index.php/panjar/article/view/28461

Hussain, M. (2015). Book review: Qualitative research in education: Interaction and practice. Journal of Education and Educational Development, 2(1), 88-93. https://doi.org/10.22555/joeed.v2i1.50

Kuhlthau, C. C., \& Maniotes, L. K. (2010). Building guided inquiry teams for 21st-century learners. School Library Monthly, 26(5), 18-21. https://www.eduscapes.com/instruction/articles/articlestoupload/kulthau.pdf

Kuhlthau, C. C., Maniotes, L. K., \& Caspari, A. K. (2015). Guided inquiry: Learning in the 21st century (2nd ed.). ABCCLIO.

Kurniashih, R., Syarifuddin, H., \& Darmansyah, D. (2019). The influence of guided inquiry learning model on students' mathematical problem solving ability. Advances in Social Science, Education and Humanities Research, 178(1), 358-362. https://doi.org/10.2991/icoie-18.2019.78

Maisyarah, S., \& Prahmana, R. C. I. (2020). Pembelajaran luas permukaan bangun ruang sisi datar menggunakan pendekatan Pendidikan Matematika Realistik Indonesia. Jurnal Elemen, 6(1), 68-88. https://doi.org/10.29408/jel.v6i1.1713

Moog, R. S., \& Spencer, J. N. (Eds.). (2008). Process oriented guided inquiry learning (Vol. 994). American Chemical Society.

National Mathematics Advisory Panel. (2008). Foundations for success: The final report of the National Mathematics Advisory Panel. U.S. Department of Education.

Novita, R., Prahmana, R. C. I., Fajri, N., \& Putra, M. (2018). Penyebab kesulitan belajar geometri dimensi tiga. Jurnal Riset Pendidikan Matematika, 5(1), 18-29. https://doi.org/10.21831/jrpm.v5i1.16836 
Nuriyatin, S., \& Hartono, H. (2016). Pengembangan pembelajaran penemuan terbimbing untuk meningkatkan berpikir kritis dan motivasi belajar geometri di SMP. Pythagoras: Jurnal Pendidikan Matematika, 11(2), 207218. https://doi.org/10.21831/pg.v11i2.10656

Owens, K., \& Outhred, L. (2006). The complexity of learning geometry and measurement. In A. Gutiérrez \& P. Boero (Eds.), Handbook of research on the psychology of mathematics education: Past, present, and future (pp. 83115). Sense. https://doi.org/10.1163/9789087901127_005

Özerem, A. (2012). Misconceptions in geometry and suggested solutions for seventh grade students. Procedia Social and Behavioral Sciences, 55(1), 720-729. https://doi.org/10.1016/j.sbspro.2012.09.557

Panaoura, A. (2014). Using representations in geometry: A model of students' cognitive and affective performance. International Journal of Mathematical Education in Science and Technology, 45(4), 498511. https://doi.org/10.1080/0020739X.2013.851804

Prahmana, R. C. I. (2017). Design research (Teori dan implementasinya: Suatu pengantar). Rajawali Pers.

Puspendik. (2019). Laporan hasil ujian nasional tahun pelajaran 2018-2019. Balitbang, Kemendikbud. https://hasilun.puspendik.kemdikbud.go.id/

Putra, M. I. S., Widodo, W., \& Jatmiko, B. (2016). The development of guided inquiry science learning materials to improve science literacy skill of prospective MI teachers. Jurnal Pendidikan IPA Indonesia, 5(1), 83-93. https://journal.unnes.ac.id/nju/index.php/jpii/article/view/5794

Retnawati, H., Hadi, S., Munadi, S., Hadiana, D., Muhardis, M., Apino, E., Djidu, H., Rafi, I., Yusron, E., \& Rosyada, M. N. (2019). When national examination no longer determining graduation, will students accomplish it seriously? Indonesian Journal of Educational Assessment, 2(2), 40-49. https://doi.org/10.26499/ijea.v2i2.34

Rochana, S. (2016). Pengembangan perangkat pembelajaran geometri bangun ruang SMP dengan menggunakan model guided inquiry. Pythagoras: Jurnal Pendidikan Matematika, 11(2), 219-227. https://doi.org/10.21831/pg.v11i2.10659

Rofii, A., Sunardi, S., \& Irvan, M. (2018). Characteristics of students' metacognition process at informal deduction thinking level in geometry problems. International Journal on Emerging Mathematics Education, 2(1), 89-104. https://doi.org/10.12928/ijeme.v2i1.7684

Rosdianah, R., Kartinah, K., \& Muhtarom, M. (2019). Analisis faktor penyebab kesulitan belajar matematika pada materi garis dan sudut kelas VII sekolah menengah pertama. Imajiner: Jurnal Matematika dan Pendidikan Matematika, 1(5), 120-132. https://doi.org/10.26877/imajiner.v1i5.4458

Sahrir, S., \& Ratumanan, T. G. (2018). Komparasi hasil belajar geometri pada siswa yang menggunakan model pembelajaran kooperatif dilengkapi aplikasi swishmax, pembelajaran kooperatif tanpa swishmax, dan model pembelajaran konvensional. Jurnal Pendidikan Matematika Raflesia, 3(1), 10-20. https://ejournal.unib.ac.id/index.php/jpmr/article/view/5794

Yulianti, E., Mustikasari, V. R., Hamimi, E., Rahman, N. F. A., \& Nurjanah, L. F. (2020). Experimental evidence of enhancing scientific reasoning through guided inquiry model approach. AIP Conference Proceedings, 2215(1), 050016. https://doi.org/10.1063/5.0000637

Yumiati, Y., \& Noviyanti, M. (2017). Abilities of reasoning and mathematics representation on guided inquiry learning. Journal of Education and Learning (EduLearn), 11(3), 283-290. https://doi.org/10.11591/edulearn.v11i3.6041 